\title{
PARADIGMA UTILITARIANISTIK DALAM ISTINBÂTH HUKUM ISLÂM
}

\author{
Moh. Rasyid Ridla \\ (Dosen Tetap Jurusan Tarbiyah STAIN Pamekasan)
}

\begin{abstract}
Abstrak:
Dalam perjalanan sejarahnya, hukum Islâm merupakan suatu kekuatan yang dinamis dan kreatif. Dengan berlalunya waktu, ia kemudian menjelma ke dalam kristalisasi madzhab-madzhab fiqh yang akhirnya mengarah pada penutupan pintu ijtihâd. Tentu saja, penutupan pintu ijtihâd ini secara logis mengarahkan kepada kebutuhan taqlid. Keadaan menimbulkan kesadaran para fuqahâ' menuju kebutuhan akan pembukaan kembali pintu ijtihâd. Dalam pada itu, muncul tiga pendekatan dalam kajian dan istinbâth hukum Islâm, yaitu pendekatan tekstualis, liberalis, dan kontekstualis. Pendekatan terakhir ini, yang mengembangkan paradigma utilitarianistik, lahir sebagai akibat kegagalan tektualisme dan kesewenang-wenangan dalam penafsiran al-Qur'ân sebagaimana yang dilakukan oleh kaum liberal. Namun demikian, paradigma utilitarianistik terbagi ke dalam dia bagian, yaitu utilitarianistik-literal, yang berpandangan bahwa kemaslahatan selalu ditundukkan di bawah hegemoni teks dan paradigma utilitarianistik-liberal yang memosisikan peran akal secara besar-besar dalam menentukan mashlahah.
\end{abstract}

\section{Kata Kunci:}

Istinbâth, tekstualis, kontekstualis, utilitarianistik-literal, utilitarianistik-liberal, dan mashlahah 


\section{Pendahuluan}

Dalam perjalanan sejarahnya, hukum Islâm ${ }^{1}$ merupakan suatu kekuatan yang dinamis dan kreatif. Hal ini dapat dilihat dari munculnya madzhab figh yang memiliki corak tersendiri, sesuai dengan latar belakang sosio-kultural dan politik di mana madzhab figh itu tumbuh dan berkembang. Perkembangan yang dinamis-kreatif ini, setidaknya-tidaknya didorong oleh beberapa faktor. Pertama, karena dorongan keagamaan, yakni eksistensi umat Muslim sebagai umat terbaik yang diutus untuk manusia, menyerukan kebaikan dan mencegah kemungkaran. ${ }^{2}$ Ini, setidak-tidaknya, mengindikasikan, bahwa secara normatif umat Muslim telah tercatat di Lawh al-Mahfûdz sebagai umat terbaik. Implikasinya, mereka semestinya tidak mengabaikan keistimewaan itu dengan cara melaksanakan ajaran Islâm semaksimal mungkin, dan membumikan ajaran itu dalam konteks kemanusiaan. Mereka diharapkan dapat membawa misi perubahan bagi kemanusiaan. ${ }^{3}$ Ini bisa dilakukan dengan pencarian makna Islâm sesuai dengan konteksnya dan menjadikan Islâm sebagai ajaran terbuka bagi munculnya beragam penafsiran. Apalagi hukum Islâm yang serba-mencakup diniscayakan untuk selalu dapat memberikan solusi atas berbagai persoalan baru yang dihadapi masyarakat. Dorongan keagamaan ini selalu eksis sepanjang sejarah Islâm dan mengambil bentuk dalam konsep ijtihâd yang secara tepat disebut oleh Iqbal sebagai prinsip gerak dalam struktur Islâm. ${ }^{4}$

Kedua, semakin meluasnya domain politik Islâm, terutama sejak masa khalifah kedua, 'Umar ibn al-Khaththâb, sehingga terjadi pergeseran sosial yang pada gilirannya menimbulkan sejumlah problem besar sehubungan dengan hukum Islâm yang membutuhkan

${ }^{1}$ Istilah "hukum Islâm" merupakan istilah khas Indonesia, sebagai terjemahan dari al-figh al-Islâmi atau dalam konteks tertentu terjemahan dari al-syarî'at al-Islâmî. Ia merupakan terjemahan dari istilah yang digunakan oleh para ahli hukum Barat, yaitu Islâmic Law. Di dalam al-Qur'ân maupun al-Hadits, atau bahkan di kitab-kitab fiqh, sama sekali tidak dijumpai istilah hukum Islâm (al-hukm al-Islâmî).

2 Al-Qur'ân Surat Alî Imrân (3): 110.

3 Lihat Muhammad al-Râzî, Tafsîr al-Râzî; al- Tafsîr al-Kabîr wa Mafâtih al-Ghayb (Beirut: Dâr al-Fikr, t.th.), hlm. 194-195.

4 Mohammad Iqbal, The Reconstruction of Religious Thought in Islam (New Delhi: Kitab Nadj, 1982), hlm. 148. 
penanganan serius. Dengan latar belakang semacam inilah, 'Umar tampil dengan sejumlah kebijakan cerdas-radikal yang belakangan dijadikan sebagai sumber justifikasi bagi pembaruan hukum Islâm pada masa modern. ${ }^{5}$ Pada masa 'Umayah dan 'Abbasiyah, imperium kaum Muslim semakin membuana dan perubahan yang ditimbulkan juga semakin dahsyat, sehingga juga membutuhkan penyelesaian yang tuntas.

Ketiga, kemandirian para spesialis hukum Islâm dari otoritas politik. Kemandirian ini menyebabkan mereka mampu mengembangkan pemikiran hukumnya tanpa mendapatkan intervensi dari pihak penguasa sehingga selaras dengan pemahamannya masing-masing. Bahkan para penguasa, semisal, Harun al-Rasyid, memberikan angin segar bagi pengembangan ilmu pengetahuan, termasuk pengembangan hukum Islâm.

Dengan berlalunya waktu, perkembangan hukum Islâm yang progresif pada masa-masa awal kemudian menjelma ke dalam kristalisasi madzhab-madzhab figh dan hak untuk ber-ijtihâd mulai dibatasi, yang akhirnya mengarah pada penutupan pintu ijtihâd. Pada sekitar abad III H/IX M, muncul gagasan bahwa hanya ulama-ulama besar masa lampaulah yang berhak melakukan ijtihâd. Pada abad IV $\mathrm{H}$, tercapai tirik krisis di mana fuqahâ' dari berbagai madzhab Sunnî memandang bahwa bahwa seluruh permasalahan esensial telah dibahas secara tuntas. Ini merupakan semacam konsensus untuk memapankan dirinya, karena ia kurang lebih bermakna bahwa mulai saat itu tidak seorang pun yang boleh mengklaim memiliki kualifikasi untuk melaksanakan ijtihâd mutlak dan bahwa seluruh aktifitas ke depan harus dibatasi pada penjelasan, aplikasi, interpretasi doktrin yang telah dirumuskan. Penutupan pintu ijtihâd ini, sebagaimana ia biasa disebut, yang terjadi sejak abad IV H-XII H secara logis mengarahkan kepada kebutuhan taqlid, yakni suatu istilah yang secara umum dimaknai sebagai penerimaan tanpa reserve atas doktrin-doktrin yang telah mapan. ${ }^{6}$

\footnotetext{
5 Tentang sejumlah kebijakan 'Umar, lihat Mun'im A. Sirry, Sejarah Fiqh Islâm (Surabaya: Risalah Gusti, 1995), hlm. 14-17; dan Fazlur Rahman, Islâmic Methodology in History (Karachi: Central Institute of Islâmic Research, 1965), terutama bab terakhir. ${ }^{6}$ Mohammad Hasbi Ash-Shiddiqie, Pengantar Hukum Islâm (Jakarta: Bulan Bintang, 1980), hlm. 80.
} 
Keadaan di atas menimbulkan kesadaran para fuqahâ' menuju kebutuhan akan pembukaan kembali pintu ijtihâd. Namun, persoalan yang muncul kemudian adalah apakah hukum Islâm bersifat tetap, dalam arti tidak bisa disesuaian dengan kondisi kontemporer ataukah dalam batas-batas tertentu ia dapat berdialog realitas zaman. Dalam pada itu, muncul tiga pendekatan dalam kajian dan istinbâth hukum Islâm, yaitu pendekatan tekstualis, liberalis, dan kontekstualis.

\section{Pendekatan dalam Kajian Hukum Islâm}

Pada dasarnya, terdapat tiga pendekatan dalam kajian hukum Islâm, yaitu pendekatan tekstualis, liberalis, dan kontekstualis. Pendekatan deduktif-tekstualis sangat bergantung pada teks-teks suci, baik al-Qur'ân maupun al-Hadîts. ${ }^{7}$ Pedekatan ini didasarkan pada pandangan bahwa sebagai agama, Islâm mendasarkan ajarannya pada wahyu Ilâhi yang tertuang dalam al-Qur'ân yang kemudian disampaikan, dijelaskan, dan dikuatkan oleh Nabî

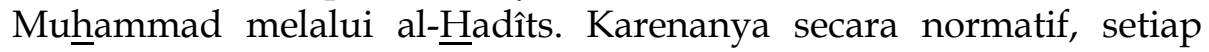
individu Muslim harus mendasarkan segala aktifitas hidupnya kepada kedua sumber asasi dalam Islâm tersebut. Pendasaran itu dilakukan dengan memberikan tekanan pada pemaknaan yang bersifat monistik, yakni pemaknaan yang berangkat dari anggapan bahwa lafdz dan makna teks merupakan satu kesatuan tunggal yang tidak terpisahkan. Implikasinya, ia kurang atau bahkan tidak memberikan ruang bagi persoalan historisitas.

Dalam sejarah hukum Islâm, kelahiran pendekatan ini dibidani oleh Dâwud al-Dzâhirî. ${ }^{8}$ Menurutnya, maksud syara' hanya dapat diketahui dari lafdz teks sebagaimana apa adanya yang tersurat. Karenanya, kaum Dzâhirîyah tidak memerlukan bantuan di luar teks

\footnotetext{
7 Amin Abdullah, "Kajian Ilmu Kalam di IAIN Menyongsong Perguliran Keilmuan KeIslâman pada Era Millenium Ketiga", Al-Jami'ah, Vol. VI No. 65 (2000), hlm. 84.

8 Nama lengkapnya adalah Abû Sulaymân Dawûd ibn 'Alî al-Asfihanî al-Dzâhirî. Ia dilahirkan dilahirkan di Kufah pada $202 \mathrm{H}$ dan wafat di Baghdad pada 270 pada usia 68 tahun. Sejak kecil, ia memang sudah bertotak cerdas, sehingga wajar jika kemudian ia menjadi seorang ahli fiqh atau bahkan menjadi seorang mujtahid mustaqil. Ia juga dikenal sebagai $\underline{h} u f f a d z$ al-hadits. Semula ia merupakan pengikut madzhab Syâfi'î, tetapi karena terjadi perbedaan pendapat tentang qiyâs, ia kemudian mendirikan madzhab sendiri. Baca Abû Zahrah, Târîkh al-Madzâhib al-Fiqhiyah (Kairo: Mathba' al-Madani, tt.)
} 
di dalam istinbâth hukum, seperti mashlahah mursalah, ${ }^{9}$ istihnsân, maupun qiyâs. Tetapi, walaupun mereka tidak bergeming dalam pandangan tekstualisnya, mereka tidak berpandangan sempit dan kaku dalam istinbâth hukum. Mereka menerapkan tåwîl ketika terdapat teks lain yang mengeluarkan dari makna lahirnya. ${ }^{10}$

Salah seorang ahli hukum pendukung pendekatan ini adalah Ibn Hazm. ${ }^{11}$ Ia adalah seorang tokoh madzhab al-Dzâhirî yang berpegang pada metode istinbâth secara naqliyah, yakni suatu metode istinbâth yang bertumpu pada teks, tidak kepada $t a^{\prime}$ wîl dan tidak pula kepada ta'lîl hukumnya. Menurutnya, teks yang bersifat lahiriyah itu telah memenuhi kebutuhan manusia, sehingga tidak diperlukan lagi peranan akal untuk menetapkan suatu hukum. ${ }^{12}$ Konsekwensinya, ia menolak semua mekanisme ijtihâd yang meniscayakan penggunaan akal, seperti qiyâs, mashlahah mursalah, istiḩsân, dan sebagainya.

Namun demikian, keyakinan bahwa kesetiaan pada teks alQur'ân dan al- Hadîts cukup untuk memecahkan persoalan ternyata

\footnotetext{
9 Penolakan atas penggunaan mashlahah mursalah oleh kaum Dzâhiriyah, antara lain, didasarkan pada pandangan bahwa berpegang kepada mashlahah mursalah berarti mengotori kesucian hukum Islâm karena ulah orang-orang yang dikendalikan oleh hawa nafsu untuk mencapai maksud dan ambisi mereka dengan mengatasnamakan mashlahah mursalah karena terjadinya nilai kemaslahatan sesuai dengan perkembangan ruang dan waktu. Lihat Wahbah al-Zuhaylî, Ushûl al-Fiqh al-Islâmî, Vol. 2 (Damaskus: Dâr al-Fikr, 1986), hlm. 761.

${ }^{10}$ Ibn Hazm, Al-Ihkâm fì Ushûl al-Ahkâm, Juz I (Mesir: al-'Ashimat, t.th.), hlm. 42.

11 Nama lengkapnya adalah 'Alî ibn Ahmad ibn Sa'îd ibn Hazm ibn Ghâlib ibn Khalaf al-Andalûsî. Ia lahir di manta Lisham, sebelah timur Cordoba pada 7 Nopember 994 $\mathrm{M}$ dan meninggal dunia di kampong halamannya pada $456 \mathrm{H}$ pada usia 71 tahun. Ia mula-mula mempelajari figh madzhab Mâlikî, sebagai resmi pemerintah dan berkembang di Andalusia. Ia banyak menemukan kelemahan dalam madzhab Mâlikî baik dalam masalah ushul maupun furû'. Ia kemudian pindah ke madzhab Syâfi'î. di madzhab Syâfi'î pun ia tidak bertahan lama karena ia menjumpai dalik-dalil yang dijadikan pegangan Imâm Syâfi'î untuk menjadikan istiḩsân ternyata dapat juga digunakan untuk membatalkan qiyâs dan beragam ijtihâd. Akhirnya, ia menjadi pengikut setia madzhab Dzâhiri karena ada kesamaan paradigma dalam istinbâth alahkâm. Baca Zahrah, Târîkh al-Madzâhib, terutama halaman 381-186. Baca juga Ahmad ibn Nashr al-Hamd, Ibn Hazm wa Mawâqifuhu al-Ilâhiyyat 'Ard wa Naqd (Makkah: AlMamlakah al-'Arabiyyah al-Su'ûdiyah, t.th.).

12 Zahrah, Târîkh al-Madzâhib, hlm. 419.
} 
hanya simplikasi. Ada beberara kegagalan paradigma tekstualisme. ${ }^{13}$ Pertama, tekstualisme menyingkirkan pengalaman mistikal dari kehidupan beragama. Kaum sufi, yang mencoba menangkap makna batiniyah dari nash-nash, dianggap sesat. Praktik-praktik keagamaan yang tidak secara spesifik ditunjukkan dalam teks, dianggap bid'ah. Selanjutnya, yang disebut bid'ah adalah apa saja yang tidak merujuk pada dalil yang telah dipilihnya. Dengan menyingkirkan mistisisme, kaum skripturalis telah menghilangkan pengalaman beragama (religious experiences) yang emosional. Para pengikutnya tidak lagi "menikmati" agama dan sebagian mengalami ketidakpuasan rohaniah.

Kedua, tekstualisme, karena menolak wacana intelektual, mudah mendorong orang ke arah fanatisme. Madzhab yang lain akan dianggap menyimpang dari al-Qur'ân dan sunnah. Dalam skala makroskopis, paham ini melahirkan orang-orang yang wawasannya sempit, tapi merasa fâqih. Pada tahap institusional, orang-orang awam tidak merasa perlu lagi dengan kehadiran fuqahâ'. Bukankah segala persoalan dapat diselesaikan dengan merujuk pada dalil-dalil al-Qur'ân dan Hadîts. Muncullah para "mujtahid" yang tidak berkualifikasi. Mereka membentuk kelompok-kelompok, yang memuncak pada fragmentasi umat.

Ketiga, tekstualisme tidak dapat menyelesaikan kemusykilankemusykilan yang terjadi ketika melakukan istidlâl (memberikan dalil-dalil hukum) dari nash-nash. Al-masâil al-lafzhiyah --seperti makna lughawî, makna 'urfî (kebiasaan), makna haqîq $\hat{\imath}$ dan majâzî, makna 'amm dan khash dan sebagainya; mukhtalaf al-hadits; penentuan keshahihan hadits; qawâ'id ushîl al-fiqh dan masalah-masalah lain yang berkaitan dengan penafsiran nash tidak mendapat perhatian.

Pendekatan kedua adalah pendekatan liberalis, yakni sebuah pendekatan yang tidak bersandar makna tekstual teks dalam istinbâth al-ahkâm, pun tidak berpegang pada dasar pemahaman yang terkandung di dalam lafdz teks. Dalam sejarah hukum Islâm, pendekatan ini diperkenalkan dan didukung oleh sekte Syî́ah bathîniyah. Mereka hanya mempercayai imâm ma'shûm. Apa pun

\footnotetext{
${ }^{13}$ Baca Jalaluddin Rahmad, Tinjauan Kritis atas Sejarah Figh: Dari Figh al-Khulafa' alRasyidin hingga Madzhab Liberalisme: http:/ / media.isnet.org/Islâm/Paramadina/ Konteks/SejarahFiqh07.html. Diakses pada 23 Februari 2008.
} 
kata imâm mereka akan selalu diikuti, karena imâm tersebut kebal dari salah dan dosa. ${ }^{14}$ Di dalam istinbâth hukum, golongan ini menerapkan penafsiran secara liberal dan tidak menggunakan kaidah-kaidah penafsiran atas teks-teks suci. ${ }^{15}$

Akibat kegagalan paradigma tekstualisme di atas ditambah kesewenang-wenangan dalam penafsiran al-Qur'ân sebagaimana yang dilakukan oleh kaum liberal, lahirlah paradigma ketiga yaitu kontekstualis. Paradigma ini mengkaitkan antara teks dan konteks. Para mujtahid yang bekerja dalam paradigma ini bisa melakukan pendekatan apa saja dalam memahami syara' dengan tetap berada pada bingkai kemaslahatan umum. Doktrin yang mereka ajukan di dalam memahami maksud teks adalah mencari makna di seberang teks apabila hasil yang diperolehnya tidak bertentangan dengan teksteks tersebut, kecuali teks tersebut bersifat mutlak. ${ }^{16}$

Paradigma ini mengembangkan suatu paham utilitarianistik ${ }^{17}$ dalam mengeksplorasi hukum Islâm, suatu pandangan yang menekankan pada asas manfaat. Ahli hukum yang pertama kali18

14 Al-Syathibî, al-Muwâfaqat, hlm. 392.

15 Muhammad 'Abd al-Adzîm al-Zarqânî, Manâhil al-'Irfân fî̀ 'Ulûm al-Qur'ân (Beirut: Dâr al-Fikr, t.th.), hlm. 75.

16 'Abd al-Wahhab al-Khalâf, 'Ilm Ushûl al-Figh (Kairo: tp., 1978), hlm. 192.

17 Madzhab utilitarianisme muncul di Barat dalam disiplin ilmu filsafat hukum Barat. Pencetusnya adalah Jeremy Bentham (w. 1832 M). menurut teori ini, tolok ukur uitility (keberuntungan) adalah kesenangan. Karenanya, ketika seseorang semakin mampu memproduksi kesenangan dan menekan kesedihan, berarti ia akan semakin mendapatkan kebahagiaan. Standar pencapaian kebahagiaan, karenanya, adalah bersifat individual. Lihat Jeffrie G. Murphy dan Jules L. Coleman, The Philosophy of Law: An Introduction of Jurisprudence (New Jersey: Rowman dan Allandheld, 1984), hlm. 74-75.

18 Namun demikian, ada juga beberapa ahli hukum yang mempunyai pandangan berbeda. Yûsûf Aḥmad Muhammad al-Badawi, misalnya, mengatakan bahwa sesungguhnya al-Syâfi'î dapat dinilai sebagai pionir paradigma utilitarianistik. Untuk mengukuhkan klaimnya, Badawi menyodorkan tiga argumen: Pertama, al-Syâfi'î seringkali berbicara perihal ratio legis hukum ('illat al-hukm) dan mengklasifikasi watak hukum menjadi rasional (ta'aqquli) dan irasional (ta'abbudi). Kedua, ia aktif menyuarakan pentingnya kaidah-kaidah universal (qawâ'id al-kuliyyah). Dan ketiga, dalam setiap proses inferensi hukum (istinbâth al-hukm), ia tidak pernah mengesampingkan tujuan-tujuan hukum. Alasan terakhir ini dikukuhkan oleh hikayah Juwayni (w. $478 \mathrm{H}$ ) bahwa al-Syâfi'î senantiasa mengkaji tujuan thaharah, puasa, haji, qishâsh, hudûd, qadha' dan lain-lain. Lebih lanjut baca Yûsûf Ahmad 
mengembangkan madzhab ini dalam hukum Islâm adalah alSyathibî. ${ }^{19}$ Ia mengatakan bahwa ajaran Islâm disyari'atkan tidak lain hanyalah untuk memelihara kemaslahatan umat manusia di dunia dan akhirat. ${ }^{20}$ Kemaslahatan dunia dan akhirat itu tegak di atas pemeliharaan tujuan hukum primer (dzarûriyah), ${ }^{21}$ yaitu: (1) menjaga agama (hifzh al-dîn); (2) menjaga jiwa ( hifzh al-nafs); (3) menjaga akal (hifzh al-'aql); (4) menjaga keturunan (hifzh al-nasl); (5) menjaga harta (hizh al-mâl).22 Jika kemaslahatan yang bersifat dzarûriyah itu tidak

Muhammad al-Badawî, Maqâshid al-Syarî'ah 'inda Ibn al-Taymiyyah, (Yordan: Dâr alNafầis, 2000), hlm. 75.

${ }^{19}$ Nama lengkapnya adalah Abû Ishaq Ibrahim ibn Musa al-Lakhmi al-Syathibî. Tidak ada keterangan tentang keluarganya, tetapi dari namanya, ia diduga berasal dari suku Lakhmi. Ia hidup di Granada, sebuah kota yang daerah yang paling berpengaruh di Spanyol, terutama pada abad IV M. Nama al-Syathibî sendiri menimbulkan kontroversi di kalangan sejarawan. Beberapa kalangan menyatakan bahwa nama al-Syathibî dikaitkan dengan daerah Syathiba (Xativa atau Jativa). Karenanya mereka berkesimpulan bahwa Syathibî lahir di Syathiba, kemudian pindah ke Granada. Kesimpulan ini jelas keliru, karena beberapa decade sebelumnya, yakni pada 645 H/1247 M, Syathiba sudah jatuh ke tangan orang-orang Kristen. Baca Mun'im A. Sirry, "Memperkenalkan Fiqh Abu Ishaq al-Syathibi", Jurnal Ulumul Qur'an, Vol. V No. 1 (1999), hlm. 81.

20 Abû Ishaq al-Syathibî, al-Muwâfaqat fî̀ Ushôul al-Syarî'ah, Juz II (Beirut: Dâr alMa'rifah, t.th.), hlm. 6.

21 Secara hierarkhis, al-Syathibi membaga kemaslahatan ke dalam tiga tingkatan, yaitu dharûriyât, hâjiyat, dan tahsînât. Dharûriyât artinya harus ada demi kemaslahatan hamba, yang jika tidak ada, akan menimbulkan kerusakan, misalnya rukun Islâm. Hâjiyât maksudnya sesuatu yang dibutuhkan untuk menghilangkan kesempitan, seperti rukhsah (keringanan) untuk tidak berpuasa bagi orang sakit. Tahsînât artinya sesuatu yang diambil untuk kebaikan kehidupan dan menghindarkan keburukan, seperti akhlak yang mulia, dan menutup aurat. Ibid., hlm. 4-5. Lihat juga al-Zuhaylî, Ushûl al-Figh, hlm. 1046-1051.

22 Ibid. Paparan ahli ushul al-figh atas urutan elemen maqâshid bervariasi. Menurut Ghazâlî adalah agama, jiwa, akal, keturunan, kemudian yang terakhir harta. Redaksi al-Râzî berbeda-beda, terkadang mengurutkannya dengan jiwa, harta, keturunan, agama, kemudian akal. Dalam redaksi yang lain, al-Râzî menulis dengan bentuk kata plural (jama') dan urutan yang berbeda, yakni jiwa-jiwa, akal-akal, agama-agama, harta-harta, dan keturunan-keturunan. Redaksi Qarafi juga menggunakan bentuk kata plural namun dengan urutan yang berbeda, yakni jiwa-jiwa, agama-agama, keturunan-keturunan, akal-akal, harga diri-harga diri. Syathibî mempunyai tiga redaksi yang berbeda urutannya. Al-Isnawî dalam dua redaksi juga berbeda. Dan banyak sekali redaksi-redaksi yang sangat warna-warni yang ridak perlu penulis jelaskan di sini. Warna-warni urutan pemaparan elemen maqâshid tersebut menimbulkan pertanyaan apakah hirarki elemen maqâshid berlaku pada tataran 
terpelihara, maka dunia tidak akan terwujud. Begitu juga akhirat tidak akan terwujud tanpa dunia.

Dalam bingkai metodologis, ia mengembangkan kerangka kerja ilmiah melalui observasi-induktif (istiqrâ'), yakni penelitian terhadap sejumlah dalil-dalil juz ${ }^{\imath}$-partikular menuju capaian hukum yang kullî-universal. Sebuah penelitian yang tentu saja tidak terkungkung pada aksara, melainkan mengeksplorasi ke kedalaman huruf untuk mendapatkan nilai-nilai maqâshid al-syarî'ah. ${ }^{23}$ Untuk menentukan apakah sebuah persoalan termasuk ke dalam kategori mashlahah atau mafsadah, harus dikembalikan atau dilihat unsur yang menunjukkan angka dominan di antara keduanya. Ini didasarkan pada suatu pemikiran bahwa tidak ditemukan di dunia suatu mashlahah yang tidak diikuti oleh mafsadah, sebagaimana juga tidak ada mafsadah tanpa mengandung nilai-nilai mashlahah di dalamnya. ${ }^{24}$

Kerangka metodologis ini dinilai oleh beberapa kalangan, seperti Mahmasani, sesungguhnya mendahului para perumus filsafat hukum di Barat, seperti Montesquieu, yang memperkenalkan gagasan bahwa evolusi hukum terjadi secara kondisional, tergantung tempat, waktu, dan perubahan situasi. ${ }^{25}$ Intinya, al-Syathibî mengembangkan konstruksi metodologi figh berbasis kepedulian sosial. Tentu saja, "cetak tebal" tidak hanya terletak pada kemapanan metodologi fighnya, tetapi juga keberaniannya menerobos status quo para fuqahấ menghadapi problem-problem baru dan mendobrak sikap simplistis. Munculnya kesenjangan antara fiqh dan perubahan sosial, menurut alSyathibî, merupakan akibat dari fuqahâ' yang sudah merasa puas dengan menghimpun dan membukukan hukum-hukum, permasalahan-permasalahan, dan hasil-hasil ijtihâd masa lalu. Selanjutnya, mereka dijadikan teks dan terakhir dikeluarkan kembali

praktek operasional atau hanya redaksinal? Zaghifah menyimpulkan bahwa hirarki tidak berlaku pada tataran praktek operasional, karena jika hirarki berlaku pada tataran operasional, maka meniscayakan munculnya kesemrawutan hukum dalam perkara furu'iyyah yang justeru dapat menyebabkan maqâshid al-Syar'iyah tidak lagi menjadi nilai universal. Baca Jamâl al-Dîn 'Athiyyah, Nahwa Tafîl Maqâshid alSyarî'ah, (Damaskus: Dâr al-Fikr, 2001), hlm. 96-100.

${ }_{23}$ Muhammad 'Abid al-Jabirî, Bunyah al-'Aql al-'Arabi, (Bairut: Markâz Dirâsah alWahdah al-'Arabiyyah, 2004), hlm. 540-541

24 Al-Syathibî, al-Muwâfaqât, hlm. 25-26.

25 Subhi Mahmasani, Muqaddimah fî Ihyâ' 'Ulûm al-Syar'iyyah (Beirut: Dâr al-Fikr, 1962), hlm. 22. 
guna menjawab sejumlah persoalan yang muncul belakangan. Hukum-hukum yang dikeluarkan sejumlah ulama' terdahulu diupayakan menjadi pengganti paling berharga dari kekeringan pemikiran dan kebekuan ilmiyah mereka. ${ }^{26}$ gugatan al-Syathibî ini mengandung nilai universal, bahka jika hendak menyikapi persoalan kontemporer secara kreatif, maka pemikiran atas pemikiran para ulama' terdahulu seharusnya bukan dalam bentuk pelestarian hukum itu apa adanya, dan dengan cara mendialogkan secara kreatif-dinamis dengan kondisi mutakhir.

Gagasan-gagasan ahli ushul klasik-utulitarisnis, terutama alSyathibî, kemudian menjadi paradigma mapan dalam kesadaran metodologis 'Abduh dan Ridhâ. Indikasi yang menunjukkan hal ini adalah kesepakatan Abduh dan Ridhâ dengan postulat teoritis Syathibî ala Muktazilî yang menyatakan bahwa "hukum Tuhan ditetapkan untuk kemaslahatan manusia".27 Namun, Abduh dan Ridhâ tidak menawarkan gagasan baru, melainkan hanya sekedar mencoba mengartikulasikan konsep maqâshid al-syarî'ah yang ditelorkan oleh ahli ushul sebelumnya.

Selain 'Abduh dan Ridhâ, Hallaq juga mengkategorikan 'Allal al-Fasi sebagai penganut religius. Al-Fasi dengan kecenderungan rasionalnya berambisi mengimplementasikan ide-ide maqâshid alSyathibi dalam ranah isu-isu kontemporer. ${ }^{28}$ Fasi yakin bahwa dialektika antara teori maqâshid dengan isu-isu kontemporer akan menciptakan keharmonisan yang sinergi antara maqâshid dengan realitas sosial yang belakangan senjang. Untuk mewujudkan impian adiluhung itu, Fasi harus rela menceburkan dirinya dalam persoalanpersoalan kompleks seperti keadilan sosial, egalitarianisme (musâwah), poligami, freedom (huriyyah), hak asasi manusia, sistem demokrasi, dan sebagainya. ${ }^{29}$

26 Sirry, Memperkenalkan, hlm. 88.

${ }^{27}$ Hammadi al-'Ubaydi, al-Syathibî wa Maqâshid al-Syarî'ah (Tripoli: Lajnah al-Huffadz 'alâ al-Turâts al-Islâmî, 1992), hlm. 101. Bahkan Wael B. Hallaq secara tegas menyatakan 'Abduh dan Ridla sebagai penanut aliran utilitarianisme religius. Baca Wael B. Hallaq, Sejarah Teori Hukum Islâm: Pengantar Ushul Figh Madzhab Sunni, terj. E. Kusnadiningrat \& Abdul Haris bin Wahid, (Jakarta: PT Raja Grafindo Persada, 2000), hlm. 318

${ }^{28}$ Nûr al-Dîn Butsurî, Maqâshid al-Syarî'ah: al-Tasyrî' al-Islâmî al-Mu'âshir bayn Thumuh al-Mujtahid wa Qushûr al-Ijtihâd, (Bairut: Dâr al-Thali'ah, 2000), hlm. 92.

29 Ibid., hlm. 66-86. 


\section{Format Utilitarianistik- Literalistik dan Utilitarianistik-Liberalistik}

Wacana mashlahah sebagaimana diuraikan di atas melahirkan dua paradigma, yaitu paradigma litreral dan liberal. Munculnya kedua paradigma ini dipicu oleh persoalan apakah kemaslahatan (mashlahah) sebagai basis konstruksi fiqh kontekstual harus tunduk kepada teks ataukah teks itu yang harus "berlutut" di bawah bayangbayang mashlahah. Paradigma literal mengedepankan cita rasa keberagaman ortodoks, sehingga ia dengan segala upaya berusaha menaklukkan realitas (mashlahah) di bawah otoritas teks. Sedangkan paradigma liberal justru menjadikan realitas (mashlahah) sebagai acuan yang mesti dicermati dalam menyikapi sebuah peristiwa hukum.

Para pendukung paradigma utilitarianistik-literalistik menetapkan tiga syarat dalam penerapan hukum mashlahah, yaitu: Pertama, mashlahah itu harus bersifat pasti, bukan sekedar rekaan bahwa ia memang mewujudkan suatu manfaat dan mencegah terjadinya mudharah. Kedua, mashlahah itu bukan merupakan kepentingan pribadi atau golongan minoritas, tetapi harus bersifat umum dan menjadi kebutuhan umum. Ketiga, hasil reasoning mashlahah itu tidak berujung pada terabaikannya suatu prinsip yang ditetapkan oleh teks syarî'ah. ${ }^{30}$

Dengan demikian, Peran nalar dalam merumuskan konsep kemaslahatan berada dalam posisi subordinat ketimbang teks. Dengan kata lain, sebagaimana ditegaskan oleh al-Juwaynî, kemaslahatan selalu ditundukkan di bawah hegemoni teks. Demikian juga al-Ghazâlî yang menegaskan bahwa tolok ukur kemaslahatan tidak dapat dikembalikan kepada penilaian manusia karena sangat rentan dengan dorongan nafsu insaniyah. Karenanya, tolok ukur kemaslahatan haruslah bermuara kepada kehendak atau tujuan syarî'ah yang telah digariskan di dalam teks-teks suci. ${ }^{31}$ Konsekuensinya, ijtihâd seputar maqâshid yang tidak berkulminasi

\footnotetext{
30 Ali Yafie, "Konsep Istihsan, Istishlah, Istishab, dan Mashlahat al-'Ammah", dalam Kontekstualisasi Doktrin Islâm dalan Sejarah, Budhi Munawar-Rahman (ed.) (Jakarta: Yayasan Wakaf Paramadina, 1994), hlm. 366-367.

31 Abû Hamid Muhammad ibn Muhammad Al-Ghazâlî, al-Mustashfâ min 'Ilm alUshûl, Juz I (Beirut: Dâr al-Fikr, t.th.), hlm. 286.
} 
pada teks adalah ilegal, sebab teks merupakan aksis dari seluruh cara pemecahan problematika atau peristiwa hukum.

Tetapi, bagi 'Izz al-Dîn bin 'Abd al-Salam, adalah keliru jika nalar tidak dijadikan piranti guna menentukan kemaslahatan. Untuk itu ia menilai bahwa konklusi-konklusi rasio dari beberapa obyek penelitian, adat kebiasaan, dan asumsi-asumsi yang dianggap valid, memiliki peran besar guna 'memilah' dan 'memilih' kemaslahatan dan kerusakan duniawi. Walaupun demikian, ia tidak menafikan bahwa kemaslahatan dan kerusakan ukhrawî hanya dapat diketahui melalui suara wahyu (divine revelation). 32

Peran nalar semakin mendapat kedudukan excellence di tangan al-Thûfî yang membawa gerbong utilitarianisme-liberal. Menurutnya, mendahulukan mashlahah atas teks merupakan suatu keharusan. Untuk mendukung pernyataannya ini, al-Thûfî memberikan empat landasan di dalam menelaah dan meletakkan dasar-dasar teori mashlalah, yaitu: Pertama, kemerdekaan berfikir perlu ditegakkan dalam upaya menemukan mashlahah maupun mafsadah. Akal sehat manusia mempunyai kemampuan untuk menentukan mana yang mashlahah dan mana yang mafsadah. Kedua, mashlahah merupakan dalil syar'î yang independen. Artinya, validitas kehujjahan mashlahah tidak bergantung pada teks. Sebaliknya, keberadaan mashlahah dapat ditunjukkan dengan pembuktian empiris melalui hukum-hukum kebiasaan. Ketiga, obyek penggunaan teori mashlahah adalah hukumhukum mu'âmalah dan hukum-hukum kebiasaan ('âdah). Karenanya, kajian mashlahah tidak dapat menjamah sakralitas ritus keagamaan (ibâdah mahdlah), karena yang dapat menghubungkan ibâdah dengan ajaran suci hanyalah teks dan ijmấ, bukan mashlahah. Keempat, mashlahah merupakan dalil syar'î yang terpenting, sehingga eksistensinya harus berada di atas teks dan ijma'. Prioritas mashlahah di atas teks dan ijmâ' bukan dalam wujud menafikan teks maupun ijmấ, tetapi sebaliknya mashlahah ummat diproyeksikan untuk menetralisir keumuman teks dan ijmấ. Bisa juga, menjadikan mashlahah sebagai pengejawentahan penafsiran dan penjelas akhir atas teks dan ijmấ yang memiliki indikasi hukum mujmal (global),

\footnotetext{
32 'Izz al-Dîn bin Zaghifah, al-Maqâshid al-' Ammah li al-Syarî'at al-Islâmiyah, (Kairo: Dâr
} al-Shafwah li al-Thaba'ah wa al-Nasyr wa al-Tawzî', 1996), hlm. 107 
sebagaimana al- $\underline{H}$ adîts mempunyai fungsi yang sama ketika berhadapan dengan teks al-Qur'ân yang mujmal.33

Keempat konstruksi nalar al-Thûfî di atas tentu sangat kontradiktif dengan pandangan mainstream. Karena, baginya, spirit dasar syarî́at Islâm adalah kemaslahatan, sedangkan kemaslahatan itu sendiri dapat dicapai melalui akal, maka dalam menilai mashlahah atau mafsadah 'tidak diperlukan wahyu', tapi cukup melalui penalaran akal secara independen.

\section{Penutup}

Pola-pola penelisikan spirit teks versi Syathibî dan para pendukungnya secara gamblang menunjukkan bahwa peran mereka lebih tepat disebut sebagai upaya 'pengukuhan bayân', bukan transformasi ushul fiqh dari retoris ke nalar argumentatif, Peran nalar dalam merumuskan konsep kemaslahatan berada dalam posisi subordinat dan termarginalkan, dalam arti bahwa kemaslahatan selalu ditundukkan di bawah hegemoni teks. Konsekuensinya, ijtihâd seputar maqâshid yang tidak berkulminasi pada teks adalah ilegal, sebab teks merupakan pusat dari seluruh cara pemecahan problematika. Pandangan ini berbanding terbalik dengan pandangan al-Thûfî yang memosisikan peran akal secara besar-besar dalam menentukan mashlahah. Inti teorinya dikerangkakan dengan memberikan supremasi terhadap kemasalahatan dan menolak dikotomi antara kemaslahatan legal dan ilegal, sebab, menurutnya, tujuan syarî'at adalah kemaslahatan yang senantiasa harus digapai, baik didukung maupun tidak oleh teks-teks Ilâhiyyah. Wallâh a'lam bi al-shawâb.

\section{Daftar Pustaka}

${ }^{33}$ Mushthafâ Zayd, al-Mashlahah fî Tasyrî' al-Islâmî (Beirut: Maktabah Wahdah, t.th.), hlm.233-235. Bandingkan dengan Muhammad Sa'id Ramadhâ al-Bûthî, Dhawâbit alMashlahah fí al-Syarî'ah al-Islâmiyyah, (Muassasah al-Risâlah: Dâr al-Muttahidah, 2000), hlm. 127-133. 
Abdullah, Amin. "Kajian Ilmu Kalam di IAIN Menyongsong Perguliran Keilmuan KeIslâman pada Era Millenium Ketiga", Al-Jami'ah, Vol. VI No. 65 (2000)

'Athiyyah, Jamâl al-Dîn. Nahwa Taf îl Maqâshid al-Syarî'ah. Damaskus: Dâr al-Fikr, 2001

Badawî, Yûsûf Aḥmad Muhammad al-. Maqâshid al-Syarî'ah 'inda Ibn al-Taymiyyah. Yordan: Dâr al-Nafầis, 2000

Bûthî, Muhammad Sa'id Ramadhâ al-. Dhawâbit al-Mashlahah fì alSyarî'ah al-Islâmiyyah. Muassasah al-Risâlah: Dâr al-Muttahidah, 2000

Butsurî, Nûr al-Dîn. Maqâshid al-Syarî'ah: al-Tasyrî' al-Islâmî alMu'âshir bayn Thumuh al-Mujtahid wa Qushûr al-Ijtihâd. Bairut: Dâr al-Thali'ah, 2000

Ghazâlî, Abû Hamid Muhammad ibn Muhammad Al-. al-Mustashfâ min 'Ilm al-Ushûl, Juz I. Beirut: Dâr al-Fikr, t.th.

Hallaq, Wael B. Sejarah Teori Hukum Islâm: Pengantar Ushul Figh Madzhab Sunni, terj. E. Kusnadiningrat \& Abdul Haris bin Wahid. Jakarta: PT Raja Grafindo Persada, 2000

Hamd, Aḥmad ibn Nashr al-. Ibn ㅂazm wa Mawâaifuhu al-Ilâhiyyat 'Ard wa Naqd. Makkah: Al-Mamlakah al-'Arabiyyah alSu' ûdiyah, t.th.

Hazm, Ibn. Al-Ihkâm fî Ushîul al-Ahkâm, Juz I. Mesir: al-'Ashimat, t.th.

Iqbal, Mohammad. The Reconstruction of Religious Thought in Islâm. New Delhi: Kitab Nadj, 1982

Jabirî, Muhammad 'Abid al-. Bunyah al-'Aql al-'Arabî. Bairut: Markâz Dirâsah al-Wahdah al-'Arabiyyah, 2004

Khalâf, 'Abd al-Wahhab al-. 'Ilm Ushûl al-Figh. Kairo: tp., 1978 
Mahmasani, Subhi. Muqaddimah fî̀ Ihyâ' 'Ulûm al-Syar'iyyah. Beirut: Dâr al-Fikr, 1962

Murphy, Jeffrie G. dan Coleman, Jules L. The Philosophy of Law: An Introduction of Jurisprudence. New Jersey: Rowman dan Allandheld, 1984

Rahmad, Jalaluddin. Tinjauan Kritis atas Sejarah Fiqh: Dari Fiqh alKhulafa' al-Rasyidin hingga Madzhab Liberalisme: http://media.isnet.org/Islâm/Paramadina/Konteks/SejarahFiq h07.html. Diakses pada 23 Februari 2008.

Rahman, Fazlur. Islâmic Methodology in History. Karachi: Central Institute of Islâmic Research, 1965

Râzî, Muhammad al-. Tafsîr al-Râzîi; al- Tafsîr al-Kabîr wa Mafâtih alGhayb. Beirut: Dâr al-Fikr, t.th.

Shiddiqie, Mohammad Hasbi Ash-. Pengantar Hukum Islam. Jakarta: Bulan Bintang, 1980

Sirry, Mun'im A. "Memperkenalkan Fiqh Abu Ishaq al-Syathibi", Jurnal Ulumul Qur'an, Vol. V No. 1 (1999)

-------. Sejarah Figh Islam. Surabaya: Risalah Gusti, 1995

Syathibî, Abû Ishaq al-. al-Muwâfaqat fî Ushûl al-Syarî'ah, Juz II. Beirut: Dâr al-Ma'rifah, t.th.

'Ubaydi, Hammadi al-. al-Syathibî wa Maqâshid al-Syarî'ah. Tripoli: Lajnah al-Huffadz 'alâ al-Turats al-Islâmî, 1992

Yafie, Ali. "Konsep Istihsan, Istishlah, Istishab, dan Mashlahat al'Ammah", dalam Kontekstualisasi Doktrin Islâm dalan Sejarah, ed. Budhi Munawar-Rahman. Jakarta: Yayasan Wakaf Paramadina, 1994 
Zaghifah, 'Izz al-Dîn ibn. al-Maqâshid al-'Âmmah li al-Syarî'at alIslâmiyah. Kairo: Dâr al-Shafwah li al-Thaba'ah wa al-Nasyr wa al-Tawzî', 1996

Zahrah, Abû. Târîkh al-Madzâhib al-Fiqhiyah. Kairo: Mathba' alMadani, tt.

Zarqânî, Muhammad 'Abd al-Adzîm al-. Manâhil al-'Irfân fî̀ 'Ulûm alQur'ân. Beirut: Dâr al-Fikr, t.th.

Zayd, Mushthafâ. al-Mashlahah fî̀ Tasyrî̀ al-Islâmî. Beirut: Maktabah Wahdah, t.th.

Zuhaylî, Wahbah al-. Ushîl al-Fiqh al-Islâmî, Vol. 2. Damaskus: Dâr alFikr, 1986 